\title{
Septic arthritis: immunopathogenesis, experimental models and therapy
}

\author{
Priscila Maria Colavite and Alexandrina Sartori
}

\begin{abstract}
Septic arthritis is an inflammatory disease of the joints that is started by an infection whose most common agent is Staphylococcus aureus. In this review we discuss some of the most arthritogenic bacterial factors and the contribution of innate and specific immune mechanisms to joint destruction. Special emphasis is given to the induction of experimental arthritis by S. aureus in mice. The improvement of therapy by association of antibiotics with down-modulation of immunity is also included.
\end{abstract}

Keywords: Septic arthritis, Staphylococcus aureus, Mice

\section{Introduction}

Septic arthritis (SA), also called infectious arthritis, is an inflammatory disease of the joints that is started by an infectious agent. Typically, SA involves one large joint such as the knee or hip but can also affect any other joint. The general estimated incidence of this pathology in industrialized countries is about 6 cases per 100,000 persons per year, with the highest rates being found in those under 15 and over 55 years old [1]. The most important risk factor for SA is preexisting joint pathologies, especially rheumatoid arthritis or prosthetic joint surgery. In these patients, SA incidence increases to 70 per 100,000 persons [2]. SA is generally considered a secondary infection, that is, the bacterium escapes from the bloodstream and enters the surrounding tissues. A number of strategies such as endothelial attachment, transcytosis, paracytosis and bacterial transportation by professional phagocytes have been described as putative mechanisms that allow the infectious agent to disseminate from the blood to the joint or other tissues [3].

Host and bacterial factors are considered to be of pathogenic importance during SA. The initial focus of joint destruction is usually the cartilage-synovium junction, with pannus formation and subsequent cartilage and bone destruction. There is an inflammatory process characterized by a rapid recruitment of polymorphonuclear granulocytes

\footnotetext{
* Correspondence: sartori@ibb.unesp.br

Departamento de Microbiologia e Imunologia, Instituto de Biociências, Universidade Estadual Paulista (UNESP), Distrito de Rubião Júnior, s/n,
} Botucatu, São Paulo State, Brazil and activated macrophages soon followed by T cells $[4,5]$. This process leads to irreversible loss of joint function and is associated with the production of a variety of cytokines $[6,7]$. The speed and accuracy of treatment are decisive for the outcome of SA. Even the delay of a few days in treatment may lead to permanent joint destruction and an increased mortality rate. The immunopathogenic process and the treatment will be explained below.

\section{Review \\ Causative agents}

The most common causative organism in both children and adult SA is Staphylococcus aureus [8,9]. S. aureus is the primary cause of bacterial arthritis in $40 \%$ of cases from England and Wales, 56\% of cases from France and $37 \%$ of cases from tropical Australia [10-12].

Interestingly, the isolation of $S$. aureus from arthritis lesions increases to $80 \%$ in joint infections in patients with concurrent rheumatoid arthritis (RA) and in those with diabetes. This predominance of $S$. aureus has been mainly attributed to its arthritogenic virulence factors that will be described below. Streptococci from groups A, B, C and G are also commonly isolated from SA in immunocompromised hosts or in patients with severe gastrointestinal or genitourinary infections [13]. Streptococcus pneumoniae, Escherichia coli, Proteus sp., Salmonella sp., Serratia marcescens, and Neisseria sp. have also been reported as causal agents of SA [1]. It has been estimated that no causative agent is identified in around half of the patients because the severity of this 
pathology requires a prompt therapy, even before the isolation of the infectious agent.

\section{Virulence factors related to arthritogenicity}

A variety of virulence factors are associated with the ability of a pathogen to trigger SA. However, in this review, we will consider some of the ones related to S. aureus due to its status as the most prevalent microorganism in human SA and also the one that causes the most severe joint disease [3]. Some virulence factors are directly related to the ability of $S$. aureus to colonize the joint whereas others are related to the effect of the bacterium on host immunity. Some of these virulence elements are classified as adhesins because they allow the bacteria to adhere to certain tissues initiating the infection. Two main adhesin types have been described as responsible for the initial anchoring of $S$. aureus in the joints: the clumping factors (ClfA and $\mathrm{B}$ ) and fibronectin-binding proteins (FnBPA and B).

ClfA is a surface protein that binds to fibrinogen and fibrin [14]. The main properties of ClfA, associated with the ability of $S$. aureus to cause disease, were established in a rat model of endocarditis. This adhesin is able to clump bacterial cells and to promote their adherence to blood clots, to plasma-conditioned biomaterials and to catheter-damaged heart valves [14-16]. The contribution of ClfA to the pathogenesis of S. aureus SA was evaluated in a murine model. Arthritis severity was strikingly reduced in mice intravenously infected with a ClfA mutant devoid of this molecule in comparison to mice infected with the wild-type bacteria that expressed ClfA. Additionally, previous active immunization with ClfA or passive immunization with anti-ClfA antibodies determined a less severe arthritis [17].

Collagen-binding protein is another adhesin that was originally isolated from the cell surface of $S$. aureus. This protein was able to mediate the attachment of $S$. aureus cells to cartilage [18]. The arthritogenic properties of this molecule were studied with two classes of $S$. aureus mutants. In the first class of mutants, the isolated collagen adhesin gene was inactivated while in the second mutant type the intact gene was introduced into an $S$. aureus strain that lacked the gene. The majority of the animals injected with the strain containing the gene developed arthritis whereas only a small proportion of the ones injected with the strain lacking this gene developed symptoms of the disease [19].

The fibronectin-binding proteins (FnBPs) A and B expressed by $S$. aureus recognize fibronectin, fibrinogen and elastin [20-22]. These proteins enable staphylococcal adherence and further invasion of different cell types, such as epithelial and endothelial cells, fibroblasts, and osteoblasts $[23,24]$. Through the formation of a fibronectin bridge to the fibronectin-binding integrin $\alpha 5 \beta 1$ expressed on the host cell surface, FnBPs trigger bacterial invasion [23-25]. It has been suggested that this invasion might provide a mechanism by which the staphylococci evade host defenses and avoid being killed by antibiotics.

More recently, the biofilm-forming capacity has been considered a major virulence determinant in S. aureus infection [26]. Biofilms are communities of bacterial cells, present on a surface, that are held together by a matrix of extracellular substances from both the bacteria and the host. Implanted medical devices have been described as the most characteristic support for these bacterial colonies [27]. It has been suggested that articular structures could also serve as a support for the growth of these bacterial communities [28]. The possible correlation between arthritogenicity of $S$. aureus strains and their ability to form biofilms is not well established and deserves a thorough investigation.

The elevated virulence of $S$. aureus compared to other infectious agents has been, at least partially, attributed to the many immune evasion strategies presented by this pathogen [29]. Some of these evasion mechanisms such as the expression of an extracellular capsule, the release of formylated peptides and the production of molecules endowed with superantigenic properties have been correlated with higher arthritogenicity. The extracellular capsule contains polysaccharides; among 11 reported capsular serotypes, types 5 (CP5) and 8 (CP8) comprise $80-85 \%$ of all clinical isolates from blood. By using CP5 mutants that did not express the capsule, Nilsson et al. [30], demonstrated that the presence of CP5, in comparison to its absence, leads to a higher frequency of arthritis and also to a more severe form of the disease. This higher arthritogenicity of the CP5 strain was attributed to the down-regulatory property of this structure on the ingestion and intracellular killing capacity of phagocytes. Formylated peptides are released by the bacterium allowing the recruitment of neutrophils into synovial tissue, thus contributing to joint destruction [31-34].

In addition, $S$. aureus produces and secretes a large number of enzymes and toxins that have been implicated in infectious arthritis [35]. A subset of these molecules displays superantigenic properties; that is, they possess the unique ability to activate a large number of $\mathrm{T}$ lymphocytes expressing certain $\mathrm{V} \beta$ sequences. As the human genome encodes approximately 50 TCR V $\beta$ elements, it has been estimated that these superantigens (SAg) can activate up to $20 \%$ of the T cell pool [36]. This $\mathrm{V} \beta$ recognition is simultaneously associated with binding to antigen-presenting cells via MHC class II molecules. These interactions result in $\mathrm{T}$ cell proliferation and a substantial cytokine release by both cell types [37,38]. The contribution of SAg to SA has been clearly observed in experimental arthritis [39-41]. Even though the toxic 
shock syndrome toxin-1 (TSST-1) SAg has been more frequently (47\%) found in the synovial fluid of patients with SA, enterotoxin C was also found in $39 \%$ of the cases [42].

\section{Immunopathogenesis}

As stated previously, S. aureus is the leading cause of all cases of infectious arthritis. Therefore, the immunopathogenetic characteristics described below are all related to this etiological agent. The investigation of SA in humans is hampered by the difficulty not only of establishing the infection onset time but also of obtaining tissue samples from the different components of the joint such as the synovial membrane, the cartilage and the subchondral bone. Therefore, most of the information detailed below originated from experimental arthritis in mice infected with $S$. aureus.

It is well established that, in addition to bacterial virulence factors, the host immune response plays an important role in the joint-damaging process. Clinically, experimental arthritis occurs in both fore and hind paws and is characterized by visible erythema and edema. Histopathological analysis of swollen joints shows hypertrophy and proliferation of the synovial tissue, inflammation, pannus formation as well as cartilage and bone destruction [35].

One of the hallmarks of septic arthritis is the massive inflammation that precedes cartilage and bone erosion. The local bacterial proliferation is accompanied by a rapid recruitment of polymorphonuclear granulocytes (PMNs) and activated macrophages quickly followed by $\mathrm{T}$ cells [4]. The direct contribution of bacterial products to the recruitment of PMNs was demonstrated by Gjertsson et al. [34]. Differently from eukaryotic cells, bacteria start protein synthesis with a formyl methionine residue, thus originating formylated peptides which are potent chemoattractants for PMNs [43]. These authors demonstrated that recruitment of PMNs in the synovial tissue was much more discrete in mice infected with a mutant strain lacking the ability to produce formylated peptides.

Cytokines released from macrophages such as TNF- $\alpha$, IL-1 $\beta$ and IL- 6 have been classically indicated as the major players of the severe inflammation that precedes cartilage and bone destruction during SA. These molecules stimulate osteoclast differentiation and bone resorption in a synergistic fashion [44]. TNF- $\alpha$, considered the most osteoclastogenic cytokine, activates NF-kB which in turn is associated with the survival of osteoclasts [5]. It is important to highlight, however, that these cytokines are also relevant to protect the host against the infectious agent [45]. The high significance of this protective role is illustrated by the demonstration that mice lacking the IL-1R type 1 developed a much more severe SA compared with intact controls, in response to infection with S. aureus [46].

In contrast with $B$ cells that do not seem to contribute to the course of $S$. aureus-induced SA, T cells and their cytokines are clearly involved in this disease [47]. This direct contribution was initially suggested by the presence of $\mathrm{T}$ cells, predominantly of $\mathrm{CD}^{+}$phenotype, in the affected joints from experimentally infected mice [40]. Assays targeting $\mathrm{T}$ cell cytokines confirmed participation of this $\mathrm{T}$ cell subset, and also indicated its dualistic role. Administration of IFN- $\gamma$ before or after $S$. aureus inoculation decreased mortality but also increased arthritis development [48]. IL-17 is a more recently described cytokine that is produced by $\mathrm{T}$ cell subsets and many innate-like T cells [49]. It is well established that this cytokine is an important mediator of rheumatoid arthritis in both, humans and mice [50]. Its role in S. aureus-triggered SA is, however, largely unknown. Data published by Henningsson et al. [51], suggest that IL-17A is more relevant in local rather than systemic host defense against $S$. aureus-induced arthritis. Our group recently reported that the variable arthritogenicity of S.aureus strains, isolated from biological samples, is probably related to their differential ability to induce IL-17 production [52].

As we described above, SAg can stimulate a great fraction of $\mathrm{T}$ cells, which is followed by their proliferation and subsequent secretion of cytokines and chemokines. The possible contribution of SAg such as TSST-1 to arthritis development was demonstrated by Abdelnour et al. [40,41]. Also by using a rat model, Bremell and Tarkowski [39], observed that almost all rats injected with SAg-producing S. aureus strains developed arthritis. On the other hand, only $20 \%$ of the rats injected with a strain lacking SAg developed the disease. One of the reasons why S.aureus-induced SA is considered a medical emergency is because this disease rapidly progresses to joint destruction. Contribution of metalloproteinases [53] and a rapid systemic bone resorption have been well characterized in experimental arthritis [5].

\section{Experimental models}

Animal models are considered invaluable for studying the pathogenesis of many human diseases. Rabbits intraarticularly injected with bacteria have been, for a long time, used to study SA [54]. However, as in many other diseases where immunity plays a highly relevant role, mice were lately adopted for experimental studies. The characteristics of the murine model closely mirror changes seen in human SA, mainly with regard to the elevated frequency and severity of periarticular bone erosivity [4]. Additionally, mice are extremely versatile models. First of all, their immune system, which is similar to the human counterpart in many aspects, is 
particularly well characterized. There is also a plethora of mice strains lacking (knockout mice) or overexpressing (transgenic) certain genes, which enables a deeper investigation of their contribution to the pathology being studied. The general application of this model and our own experience with it will be discussed below.

Induction of experimental arthritis by $S$. aureus infections has been successful with certain mice strains as NRMI, C57BL/6, $1295 \mathrm{~V}$ and BALB/c [55-57]. A very important aspect is the choice of the $S$. aureus strain to be used. Even though $S$. aureus is the leading cause of infectious arthritis, not all the strains are arthritogenic. Tarkowski et al. [58] greatly contributed to establishing the basis of SA models. This group usually employs a bacterial strain denominated LS-1, originally isolated from a spontaneous outbreak of $S$. aureus arthritis in a mouse colony [59]. The production of the exotoxin TSST-1 contributes to arthritogenicity since mice injected with TSST-1-producing $S$. aureus strain developed more frequently and also a more severe disease than strains that do not produce this SAg [40,41]. However, we recently observed that $S$. aureus strains able to produce other SAg such as enterotoxin $\mathrm{C}$ and enterotoxin $\mathrm{A}$ were also able to trigger SA [52]. Another relevant detail is the bacterial dose, which typically ranges from $7.10^{6}$ to $10^{7} \mathrm{~S}$. aureus colony-forming units per mouse [58].

There is a consensus that the best way to trigger SA is by the intravenous route. This procedure would better mimic the great majority of bacterial joint infections in humans that are believed to originate from the blood [11]. In our personal experience, the bacterial injection by the retro-orbital route is fast, highly effective and also generates a very homogeneous pathology. This model allows analysis of the disease development by daily joint inspection. Arthritis is defined by a visible joint erythema and/or swelling of at least one joint. To evaluate the intensity of arthritis, a clinical scoring (arthritic index) is carried out using a system where macroscopic inspection yields a score of $0-3$ points for each limb $(1$ point $=$ mild swelling and/or erythema; 2 points = moderate swelling and erythema; 3 points $=$ marked swelling and erythema). The arthritic index is constructed by dividing the total score (number of arthritic limbs) by the number of animals used in each experimental group $[40,41,52]$. An illustrative micrograph of a clinical score 2 in C57BL/6 mice infected with an S. aureus strain is shown in Figure 1. This mouse model has been extensively used to assess bacterial virulence factors [17], host defense mechanisms [58], and the immunopathogenetic mechanisms that result in joint destruction [35]. The availability of this model is also revealing interesting alternatives in the fields of prophylactic and therapeutic procedures [60,61]. A schematic outline of the main parameters that have been analyzed in this model is presented in Figure 2. More detailed informations on the application of the murine model to investigate this pathology are available in the literature $[35,58,62]$.

\section{Therapy}

The speed and accuracy of SA therapy is critical to control disease aggravation. If SA is suspected, a blood sample and an aspiration of the joint should be performed
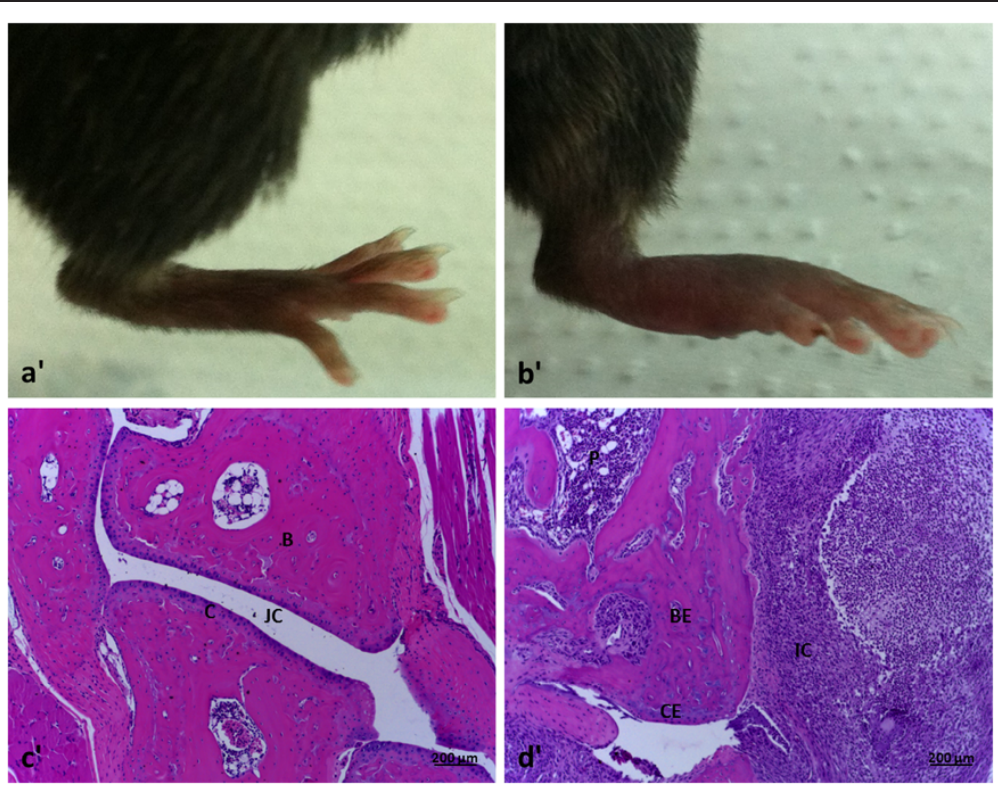

Figure 1 Clinical score 2 and corresponding histopathological analyses in a hind paw from a C57BL/6 mouse infected with enterotoxin

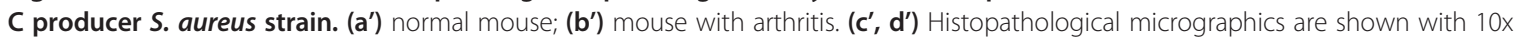
magnification. JC: joint cavity; C: cartilage; B: bone; BE: bone erosion; CE: cartilage erosion; P: pannus formation and IC: inflammatory cells. 


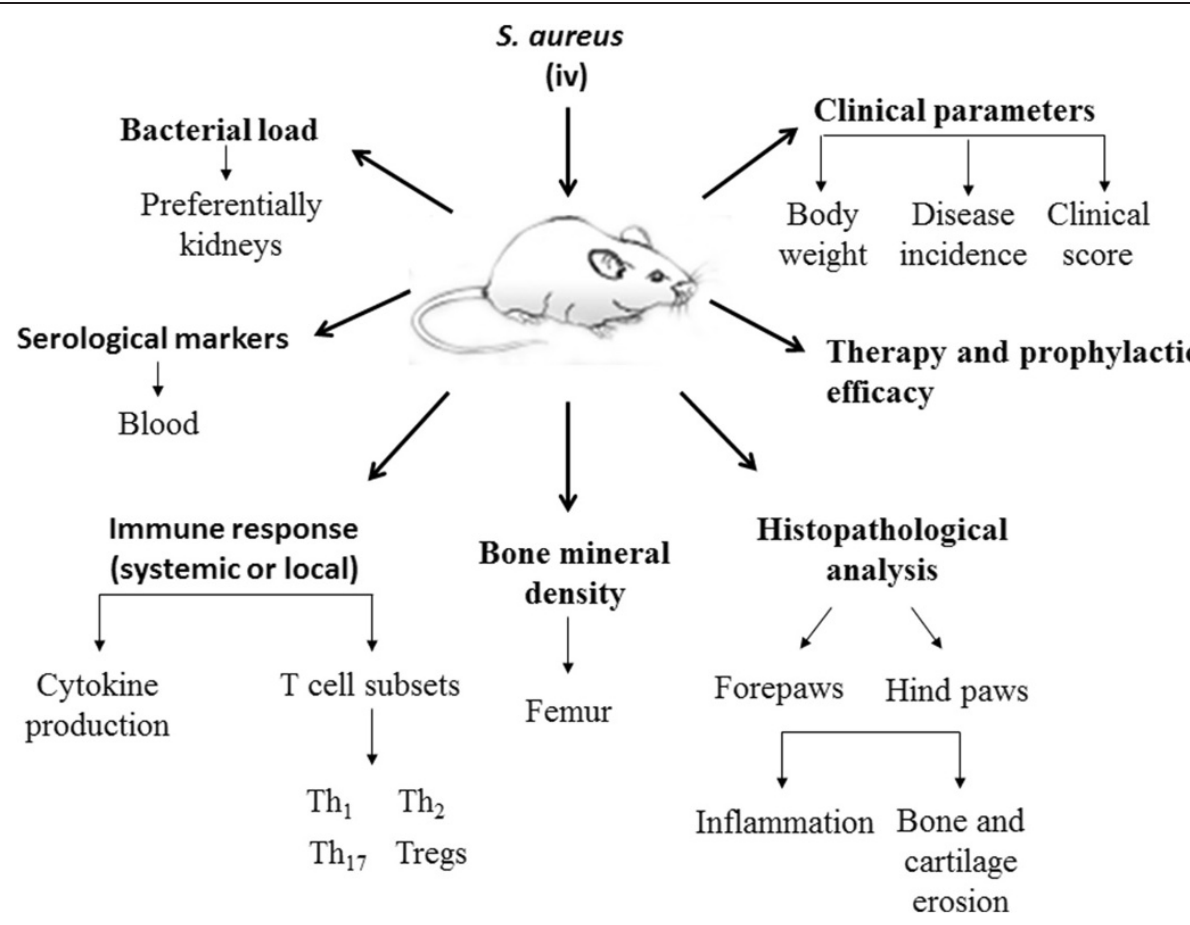

Figure 2 Schematic outline of the parameters that are most frequently analyzed in the murine SA experimental model.

before antibiotic administration. However, as soon as these procedures have been done and before the results are available, it is imperative to start treatment with broad-spectrum antibiotics [1,35]. A detailed description related to clinical management and treatment of human SA is outside of the scope of this review. However, highly informative data on this subject can be found in the literature [63-65]. There is also a consensus among the experts in the field that treatment should include the concomitant removal of any purulent material [66].

Even though it is well established that killing the bacteria is essential for controlling SA evolution, this treatment alone will not block the joint-destruction process. It has been described that after completing antimicrobial treatment, these patients recover around 46 to 50 percent of their original joint function [67]. This happens because much of the local destruction is generated by the immune response induced by the bacteria and their soluble products [35]. This realization prompted the association of antibiotics with substances able to counteract this exaggerated immune response. Experimental models have been extremely useful to test this concept. The severity of experimental SA was clearly down-regulated by the adjunctive association of corticosteroids with antibiotics $[68,69]$. The translation of this concept to treatment of human SA was confirmed [70]. This combined approach is clearly expanding in the treatment of SA and being thoroughly investigated with the help of the murine experimental model. Some of the most important findings in this field are summarized in Table 1.

\section{Conclusions}

- Septic arthritis is a severe inflammatory disease of the joints triggered by an infectious agent.

- Staphylococcus aureus causes the most frequent and severe cases of septic arthritis.

Table 1 Experimental treatments in septic arthritis

\begin{tabular}{|c|c|c|}
\hline Treatment & $\begin{array}{l}\text { Control of arthritis } \\
\text { development }(*)\end{array}$ & Reference \\
\hline $\begin{array}{l}\text { Inhibition of transcription factors } \\
\text { NF-kB and mCoAP-1 alone or } \\
\text { with antibiotics }\end{array}$ & No & [71] \\
\hline $\begin{array}{l}\text { Cloxacillin + phenyl-N-tert-butyl } \\
\text { nitrone (antioxidant) }\end{array}$ & Yes & [72] \\
\hline Cloxacillin + TNF inhibitor & Yes & {$[60]$} \\
\hline Ampicillin + riboflavin (antioxidant) & Yes & [73] \\
\hline Gentamicin + ascorbic acid & Yes & [74] \\
\hline Estradiol & Yes & [75] \\
\hline Azithromycin + riboflavin & Yes & [76] \\
\hline Glutaminyl cyclase inhibitors & Yes & [77] \\
\hline
\end{tabular}

(*) Control of arthritis development was assessed by the following parameters: delayed disease development, less severe clinical manifestations or reduced swelling or synovitis. 
- Joint destruction is determined by both bacterial and host factors.

- Mice experimentally infected with $S$. aureus strains are widely employed to study this disease.

Mice were manipulated in accordance with the ethical guidelines adopted by the Brazilian College of Animal Experimentation. All experimental protocols were approved by the local ethics committee for animal experimentation (CEEA), Medical School, Univ. Estadual Paulista (protocol number 291).

\section{Abbreviations}

SA: Septic arthritis; SAg: Superantigen or superantigens; RA: Rheumatoid arthritis; ClfA: Clumping factors; FnBPs: Fibronectin binding proteins;

PMNs: Polymorphonuclear granulocytes; TSST-1: Toxic shock syndrome toxin-1.

\section{Competing interests}

The authors declare that there are no competing interests.

\section{Authors' contributions}

PMC and AS equally contributed to conceiving and writing this review. Both authors read and approved the final manuscript.

\section{Acknowledgments}

The authors would like to acknowledge the support by the State of São Paulo Research Foundation (FAPESP) under grant n. 2011/04323-3, and the National Council for Scientific and Technological Development (CNPq) under grant n. 472589/2011-3.

Received: 31 January 2014 Accepted: 22 April 2014

Published: 6 May 2014

\section{References}

1. Nade S: Septic arthritis. Best Pract Res Clin Rheumatol 2003, 17(2):183-200.

2. Kaandorp CJ, Van Schaardenburg D, Krijnen P, Habbema JD, van de Laar MA: Risk factors for septic arthritis in patients with joint disease. A prospective study. Arthritis Rheum 1995, 38(12):1819-1825.

3. Edwards AM, Massey RC: How does Staphylococcus aureus escape the bloodstream? Trends Microbiol 2011, 19(4):184-910.

4. Bremell T, Abdelnour A, Tarkowski A: Histopathological and serological progression of experimental Staphylococcus aureus arthritis. Infect Immun 1992, 60(7):2976-2985.

5. Verdrengh M, Carlsten H, Ohlsson C, Tarkowski A: Rapid systemic bone resorption during the course of Staphylococcus aureus-induced arthritis. Infect Dis 2006, 194(11):1597-1600.

6. Kong YY, Feige U, Sarosi I, Bolon B, Tafuri A, Morony S, Capparelli C, Li J, Elliott R, McCabe S, Wong T, Campagnuolo G, Moran E, Bogoch ER, Van G, Nguyen LT, Ohashi PS, Lacey DL, Fish E, Boyle WJ, Penninger JM: Activated $T$ cells regulate bone loss and joint destruction in adjuvant arthritis through osteoprotegerin ligand. Nature 1999, 402(6759):304-309.

7. Campagnuolo G, Bolon B, Feige U: Kinetics of bone protection by recombinant osteoprotegerin therapy in Lewis rats with adjuvant arthritis. Arthritis Rheum 2002, 46(7):1926-1936.

8. Clerc O, Prod'hom G, Greub G, Zanetti G, Senn L: Adult native septic arthritis: a review of 10 years of experience and lessons for empirical antibiotic therapy. J Antimicrob Chemother 2011, 66(5):1168-1173.

9. Howard-Jones AR, Isaacs D, Gibbons PJ: Twelve-month outcome following septic arthritis in children. J Pediatr Orthop B 2013, 22(5):486-490.

10. Le Dantec L, Maury F, Flipo RM, Laskri S, Cortet B, Duquesnoy B, Delcambre B: Peripheral pyogenic arthritis. A study of one hundred seventy-nine cases. Rev Rhum Engl Ed 1996, 63(2):103-110.

11. Morgan DS, Fisher D, Merianos A, Currie BJ: An 18 year clinical review of septic arthritis from tropical Australia. Epidemiol Infect 1996, 117(3):423-428.

12. Ryan MJ, Kavanagh R, Wall PG, Hazleman BL: Bacterial joint infections in England and Wales: analysis of bacterial isolates over a four year period. Br J Rheumatol 1997, 36(3):370-373.
13. Goldenberg DL: Septic arthritis. Lancet 1998, 351(9097):197-202.

14. McDevitt $D$, Francois $P$, Vaudaux $P$, Foster TJ: Molecular characterization of the clumping factor (fibrinogen receptor) of Staphylococcus aureus. Mol Microbiol 1994, 11(2):237-248.

15. Moreillon P, Entenza JM, Francioli P, McDevitt D, Foster TJ, François P, Vaudaux P: Role of Staphylococcus aureus coagulase and clumping factor in pathogenesis of experimental endocarditis. Infect Immun 1995, 63 (12):4738-4743.

16. Vaudaux P, Francois P, Proctor RA, McDevitt D, Foster TJ, Albrecht RM: Use of adhesion-defective mutants of Staphylococcus aureus to define the role of specific plasma proteins in promoting bacterial adhesion to canine arteriovenous shunts. Infect Immun 1995, 63(2):585-590.

17. Josefsson E, Hartford O, O'Brien L, Patti JM, Foster T: Protection against experimental Staphylococcus aureus arthritis by vaccination with clumping factor A, a novel virulence determinant. J Infect Dis 2001, 184(12):1572-1580.

18. Gillaspy AF, Patti JM, Smeltzer MS: Transcriptional regulation of the Staphylococcus aureus collagen adhesin gene, cna. Infect Immun 1997, 65(4):1536-1540.

19. Patti JM, Boles JO, Höök M: Identification and biochemical characterization of the ligand binding domain of the collagen adhesin from Staphylococcus aureus. Biochemistry 1993, 32(42):11428-11435.

20. Jonsson K, Signas C, Müller HP, Lindberg M: Two different genes encode fibronectin binding proteins in Staphylococcus aureus. The complete nucleotide sequence and characterization of the second gene. Eur J Biochem 1991, 202(3):1041-1048.

21. Wann ER, Gurusiddappa S, Hook M: The fibronectin-binding MSCRAMM FnbpA of Staphylococcus aureus is a bifunctional protein that also binds to fibrinogen. J Biol Chem 2000, 275(18):13863-13871.

22. Roche FM, Downer R, Keane F, Speziale P, Park PW, Foster TJ: The N-terminal A domain of fibronectin-binding proteins $A$ and $B$ promotes adhesion of Staphylococcus aureus to elastin. J Biol Chem 2004, 279(37):38433-38440.

23. Sinha B, François PP, Nüsse O, Foti M, Hartford OM, Vaudaux P, Foster TJ, Lew DP, Herrmann M, Krause KH: Fibronectin-binding protein acts as Staphylococcus aureus invasin via fibronectin bridging to integrin alpha5beta1. Cell Microbiol 1999, 1(2):101-117.

24. McElroy MC, Cain DJ, Tyrrell C, Foster TJ, Haslett C: Increased virulence of a fibronectin-binding protein mutant of Staphylococcus aureus in a rat model of pneumonia. Infect Immun 2002, 70(7):3865-3873.

25. Massey RC, Kantzanou MN, Fowler T, Day NP, Schofield K, Wann ER, Berendt AR, Höök M, Peacock SJ: Fibronectin-binding protein A of Staphylococcus aureus has multiple, substituting, binding regions that mediate adherence to fibronectin and invasion of endothelial cells. Cell Microbiol 2001, 3(12):839-851.

26. Foster TJ, Geoghegan JA, Ganesh VK, Höök M: Adhesion, invasion and evasion: the many functions of the surface proteins of Staphylococcus aureus. Nat Rev Microbiol 2013, 12(1):49-62.

27. Otto M: Staphylococcal infections: mechanisms of biofilm maturation and detachment as critical determinants of pathogenicity. Annu Rev Med 2013, 64:175-188.

28. Brooks JL, Jefferson KK: Staphylococcal biofilms: quest for the magic bullet. Adv App/ Microbiol 2012, 81:63-87.

29. Kim JH, Muto CA, Pasculle AW, Vergis EN: Invasive polyarticular septic arthritis caused by nontypeable haemophilus influenzae in a young adult: a case report and literature review. I Clin Rheumatol 2011, 7(7):380-382.

30. Nilsson IM, Lee JC, Bremell T, Rydén C, Tarkowski A: The role of staphylococcal polysaccharide microcapsule expression in septicemia and septic arthritis. Infect Immun 1997, 65(10):4216-4221.

31. Switalski LM, Patti JM, Butcher W, Gristina AG, Speziale P, Höök M: A collagen receptor on Staphylococcus aureus strains isolated from patients with septic arthritis mediates adhesion to cartilage. Mol Microbiol 1993, 7(1):99-107.

32. Patti JM, Bremell T, Krajewska-Pietrasik D, Abdelnour A, Tarkowski A, Rydén C, Höök M: The Staphylococcus aureus collagen adhesin is a virulence determinant in experimental septic arthritis. Infect Immun 1994, 62(1):152-161

33. Palmqvist N, Foster T, Fitzgerald JR, Josefsson E, Tarkowski A: Fibronectinbinding proteins and fibrinogen-binding clumping factors play distinct 
roles in staphylococcal arthritis and systemic inflammation. $J$ Infect Dis 2005, 191(5):791-798.

34. Gjertsson I, Jonsson IM, Peschel A, Tarkowski A, Lindholm C: Formylated peptides are important virulence factors in Staphylococcus aureus arthritis in mice. J Infect Dis 2012, 205(2):305-311.

35. Tarkowski A: Infection and musculoskeletal conditions: Infectious arthritis. Best Pract Res Clin Rheumatol 2006, 20(6):1029-1044.

36. Proft T, Fraser JD: Bacterial superantigens. Clin Exp Immunol 2003, 133(3):299-306.

37. Baker MD, Acharya KR: Superantigens: structure-function relationships. Int J Med Microbiol 2004, 293(7-8):529-537.

38. Grumann D, Nübel U, Bröker BM: Staphylococcus aureus toxins - their functions and genetics. Infect Genet Evol 2014, 21(2014):583-92.

39. Bremell T, Tarkowski A: Preferential induction of septic arthritis and mortality by superantigen-producing staphylococci. Infect Immun 1995, 63(10):4185-4187.

40. Abdelnour A, Bremell T, Holmdahl R, Tarkowski A: Clonal expansion of T lymphocytes causes arthritis and mortality in mice infected with toxic shock syndrome toxin-1-producing staphylococci. Eur J Immunol 1994, 24(5):1161-1166.

41. Abdelnour A, Bremell T, Tarkowski A: Toxic shock syndrome toxin-1 contributes to the arthritogenicity of Staphylococcus aureus. J Infect Dis 1994, 170(1):94-99.

42. Noorbakhsh A, Talebi-Taher M, Tabatabaei A: Identification of bacterial antigens and super antigens in synovial fluid of patients with arthritis: a cross sectional study. Med J Islam Repub Iran 2013, 27(1):12-16

43. Southgate EL, He RL, Gao JL, Murphy PM, Nanamori M, Ye RD: Identification of formyl peptides from Listeria monocytogenes and Staphylococcus aureus as potent chemoattractants for mouse neutrophils. J Immunol 2008, 181(2):1429-1437.

44. Kwan Tat S, Padrines M, Théoleyre S, Heymann D, Fortun Y: IL-6, RANKL, TNF-alpha/L-1: interrelations in bone resorption pathophysiology. Cytokine Growth Factor Rev 2004, 15(1):49-60.

45. Krishna S, Miller LS: Host-pathogen interactions between the skin and Staphylococcus aureus. Curr Opin Microbiol 2012, 15(1):28-35.

46. Hultgren OH, Svensson L, Tarkowski A: Critical role of signaling through IL1 receptor for development of arthritis and sepsis during Staphylococcus aureus infection. J Immunol 2002, 168(10):5207-5212.

47. Gjertsson I, Hultgren OH, Stenson M, Holmdahl R, Tarkowski A: Are B lymphocytes of importance in severe Staphylococcus aureus infections? Infect Immun 2000, 68(5):2431-2434.

48. Zhao YX, Nilsson IM, Tarkowski A: The dual role of interferon-gamma in experimental Staphylococcus aureus septicaemia versus arthritis. Immunology 1998, 93(1):80-85.

49. Kim JS, Jordan MS: Diversity of IL-17-producing T lymphocytes. Cell Mol Life Sci 2013, 70(13):2271-2290.

50. Nakae S, Saijo S, Horai R, Sudo K, Mori S, Iwakura Y: IL-17 production from activated $T$ cells is required for the spontaneous development of destructive arthritis in mice deficient in IL-1 receptor antagonist. Proc Natl Acad Sci U S A 2003, 100(10):5986-5990.

51. Henningsson L, Jirholt $P$, Lindholm C, Eneljung T, Silverpil E, Iwakura $Y$, Linden A, Gjertsson I: Interleukin-17a during local and systemic Staphylococcus aureus-induced arthritis in mice. Infect Immun 2010, 78(9):3783-3790

52. Colavite-Machado PM, Ishikawa LLW, França TGD, Zorzella-Pezavento SFG, da Rosa LC, Chiuso-Minicucci F, da Cunha MLR, Garlet GP, Sartori A: Differential arthritogenicity of Staphylococcus aureus strains isolated from biological samples. BMC Infect Dis 2013, 13:400. doi:10.1186/14712334-13-400

53. Gjertsson I, Innocenti M, Matrisian LM, Tarkowski A: Metalloproteinase-7 contributes to joint destruction in Staphylococcus aureus induced arthritis. Microb Pathog 2005, 38(2-3):97-105.

54. Johnson AH, Campbell WG Jr, Callahan BC: Infection of rabbit knee joints after intra-articular injection of Staphylococcus aureus. Comparison with joints injected with Staphylococcus albus. Am J Pathol 1970, 60(2):165-202.

55. Hultgren O, Kopf M, Tarkowski A: Outcome of Staphylococcus aureustriggered sepsis and arthritis in IL-4-deficient mice depends on the genetic background of the host. Eur J Immunol 1999, 29(8):2400-2405.
56. Shaw LN, Lindholm C, Prajsnar TK, Miller HK, Brown MC, Golonka E, Stewart GC, Tarkowski A, Potempa J: Identification and characterization of $\sigma$ S, a novel component of the Staphylococcus aureus stress and virulence responses. PLoS One 2008, 3(12):e3844.

57. Narita K, Hu D, Mori F, Wakabayashi K, Iwakura Y, Nakane A: Role of Interleukin-17A in cell-mediated protection against Staphylococcus aureus Infection in Mice Immunized with the fibrinogenbinding domain of clumping factor A. Infect Immun 2010, 78(10):4234-4242.

58. Tarkowski A, Collins LV, Gjertsson I, Hultgren OH, Jonsson IM, Sakiniene E, Verdrengh M: Model systems: modeling human staphylococcal arthritis and sepsis in the mouse. Trends Microbiol 2001, 9(7):321-326.

59. Bremell T, Lange $S$, Svensson $L$, Jennische E, Gröndahl K, Carlsten $H$, Tarkowski A: Outbreak of spontaneous staphylococcal arthritis and osteitis in mice. Arthritis Rheum 1990, 33(11):1739-1744.

60. Fei $Y$, Wang W, Kwiecinski J, Josefsson E, Pullerits R, Jonsson IM, Magnusson $M$, Jin $T$ : The combination of a tumor necrosis factor inhibitor and antibiotic alleviates staphylococcal arthritis and sepsis in mice. I Infect Dis 2011, 204(3):348-357.

61. Harel L, Prais D, Bar-On E, Livni G, Hoffer V, Uziel Y, Amir J: Dexamethasone therapy for septic arthritis in children: results of a randomized doubleblind placebo-controlled study. J Pediatr Orthop 2011, 31(2):211-215.

62. Tarkowski A, Bokarewa M, Collins LV, Gjertsson I, Hultgren OH, Jin T, Jonsson IM, Josefsson E, Sakiniene E, Verdrengh M: Current status of pathogenetic mechanisms in staphylococcal arthritis. FEMS Microbiol Lett 2002, 217(2):125-132.

63. Mathews CJ, Coakley G: Septic arthritis: current diagnostic and therapeutic algorithm. Curr Opin Rheumatol 2008, 20(4):457-462.

64. Horowitz DL, Katzap E, Horowitz S, Barilla-LaBarca ML: Approach to septic arthritis. Am Fam Physician 2011, 84(6):653-660.

65. Sharff KA, Richards EP, Townes JM: Clinical management of septic arthritis. Curr Rheumatol Rep 2013, 15(6):332.

66. Coakley G, Mathews C, Field M, Jones A, Kingsley G, Walker D, Phillips M, Bradish C, McLachlan A, Mohammed R, Weston V, British Society for Rheumatology Standards, guidelines and audit working group: BSR \& BHPR, $B O A, R C G P$ and BSAC guidelines for management of the hot swollen joint in adults. Rheumatology (Oxford) 2006, 45(8):1039-1041.

67. Weston V, Jones A, Bradbury N, Fawthrop F, Doherty M: Clinical features and outcome of septic arthritis in a single UK Health District 1982-1991. Ann Rheum Dis 1999, 58(4):214-219.

68. Sakiniene E, Bremell T, Tarkowski A: Corticosteroids ameliorate the course of experimental, superantigen-triggered Staphylococcus aureus arthritis. Arthritis Rheum 1996, 39:1596-1605.

69. Verba V, Sakiniene E, Tarkowski A: Beneficial effects of glucocorticosteroids on the course of the hematogenously acquired Staphylococcus aureus nephritis. Scand J Immunol 1997, 45:282-286.

70. Odio CM, Ramirez T, Arias G, Abdelnour A, Hidalgo I, Herrera ML, Bolaños W, Alpizar J, Alvarez P: Double blind, randomized, placebo-controlled study of dexamethasone therapy for hematogenous septic arthritis in children. Pediatr Infect Dis J 2003, 22(10):883-888.

71. Gjertsson I, Hultgren OH, Collins LV, Pettersson S, Tarkowski A: Impact of transcription factors AP-1 and NF-kappaB on the outcome of experimental Staphylococcus aureus arthritis and sepsis. Microbes Infect 2001, 3(7):527-534.

72. Sakiniene $\mathrm{E}$, Collins LV: Combined antibiotic and free radical trap treatment is effective at combating Staphylococcus-aureus-induced septic arthritis. Arthritis Res 2002, 4(3):196-200.

73. Mal P, Ghosh D, Bandyopadhyay D, Dutta K, Bishayi B: Ampicillin alone and in combination with riboflavin modulates Staphylococcus aureus infection induced septic arthritis in mice. Indian J Exp Bio/ 2012, 50(10):677-689.

74. Mal P, Dutta S, Bandyopadhyay D, Dutta K, Basu A, Bishayi B: Gentamicin in combination with ascorbic acid regulates the severity of Staphylococcus aureus infection-induced septic arthritis in mice. Scand I Immunol 2012. 76(6):528-540.

75. Gjertsson I, Lagerquist MK, Kristiansson E, Carlsten H, Lindholm C: Estradiol ameliorates arthritis and protects against systemic bone loss in Staphylococcus aureus infection in mice. Arthritis Res Ther 2012, 14(2):R76.

76. Mal P, Dutta K, Bandyopadhyay D, Basu A, Khan R, Bishayi B: Azithromycin in combination with riboflavin decreases the severity of Staphylococcus 
aureus infection induced septic arthritis by modulating the production of free radicals and endogenous cytokines. Inflamm Res 2013,

62(3):259-273.

77. Hellvard A, Maresz K, Schilling S, Graubner S, Heiser U, Jonsson R, Cynis H, Demuth HU, Potempa J, Mydel P: Glutaminyl cyclases as novel targets for the treatment of septic arthritis. J Infect Dis 2013, 207(5):768-777.

doi:10.1186/1678-9199-20-19

Cite this article as: Colavite and Sartori: Septic arthritis:

immunopathogenesis, experimental models and therapy. Journal of

Venomous Animals and Toxins including Tropical Diseases 2014 20:19.

\section{Submit your next manuscript to BioMed Central} and take full advantage of:

- Convenient online submission

- Thorough peer review

- No space constraints or color figure charges

- Immediate publication on acceptance

- Inclusion in PubMed, CAS, Scopus and Google Scholar

- Research which is freely available for redistribution 